\title{
Konseling KB Menggunakan Flashcard terhadap Peningkatan Pengetahuan, Sikap dan Keikutsertaan Kontrasepsi IUD dan MOW Pascasalin
}

\author{
Vera Suzana Dewi Haris \\ Jurusan Kebidanan, Politeknik Kesehatan Kemenkes Jakarta I \\ Email: vera_sdh@yahoo.co.id
}

\begin{abstract}
KB Counseling Using Flashcard with Improved Knowledge, Attitudes and Participation IUD Contraception and Postpartum MOW. Flash card is an effective tool in Family planning counseling because it is easy to bring to the room when carrying out the IUD and MOW contraceptives counseling for postnatal mother program. This study aimed to measure the difference in knowledge and attitudes of a postnatal mother about IUD and MOW contraceptives before and after provision information program of family planning by flash card and measure the correlation in the increase of knowledge and attitude after provision family planning counseling by a flash card with the postnatal IUD and MOW contraceptives participation.This study uses a quasiexperimental research design with one group pretest-posttest design. There were 52 total samples fulfilling the inclusion criteria. The analysis was Wilcoxon, chi-square and point biserial test. The results showed that there was difference in knowledge and attitudes about family planning before and after IUD and MOW postnatal family planning counseling by flash card ( $\mathrm{p}$-value $=0,000$ ), there was a positive correlation between the knowledge and attitudes of postnatal mother about family planning after counseling by flash card with the postnatal IUD and MOW contraceptives participation ( $\mathrm{p}$ value $=0,001$ and 0,000 ), and there was a positive correlation between the increase of knowledge and attitude with the postnatal IUD and MOW contraceptives participation by $p$ value $=0,002$ and 0,001 by mean of weak and adequate relationship degree. The conclusions of this research are knowledge and attitude of a postnatal mother about family planning after the provision of family planning counseling by flash card is better than before the provision of family planning counseling.
\end{abstract}

Keywords: Counseling, Family planning, Flashcard, Postnatal, Knowledge, Attitude

\begin{abstract}
Abstrak: Konseling KB Menggunakan Flashcard terhadap Peningkatan Pengetahuan, Sikap dan Keikutsertaan Kontrasepsi IUD dan MOW Pascasalin. Media flash card merupakan salah satu media konseling yang efektif karena mudah dibawa ke ruangan saat pemberian konseling kontrasepsi IUD dan MOW pada ibu pascasalin. Tujuan penelitian mengukur perbedaan pengetahuan dan sikap ibu pascasalin tentang kontrasepsi IUD dan MOW sebelum dan sesudah pemberian konseling KB dengan menggunakan media flash card dan mengukur korelasi peningkatan pengetahuan dan sikap sesudah pemberian konseling KB menggunakan media flash card dengan keikutsertaan kontrasepsi IUD dan MOW pascasalin. Penelitian ini menggunakan desain quasi eksperimen dengan desain penelitian one group pretest-posttest design. Jumlah sampel adalah 52 orang dengan teknik pengambilan sampel total populasi dengan memperhatikan kriteria inklusi. Analisis yang digunakan pada penelitian ini adalah uji wilcoxon, chi-square dan point bisereal. Hasil penelitian terdapat perbedaan pengetahuan dan sikap tentang KB sebelum dan sesudah pemberian konseling KB pascasalin IUD dan MOW dengan menggunakan flash card $(p=0,000)$, terdapat hubungan pengetahuan dan sikap ibu pascasalin tentang KB sesudah pemberian konseling KB menggunakan flash card dengan keikutsertaan kontrasepsi IUD dan MOW pascasalin (nilai $p=0,001$ dan $0,000)$ dan terdapat korelasi antara peningkatan pengetahuan dan sikap terhadap keikutsertaan kontrasepsi IUD dan MOW pascasalin dengan dengan nilai $p=0,002$ dan 0,001 dengan keeratan lemah dan cukup. Pengetahuan dan sikap ibu pascasalin tentang KB setelah pemberian konseling KB dengan flash card lebih baik daripada sebelum pemberian konseling KB.
\end{abstract}

Kata kunci: Konseling, Keluarga Berencana, Flash card, Pascasalin, Pengetahuan, Sikap

Berdasarkan sensus Badan Pusat Statistik (BPS) tahun 2010, jumlah penduduk Indonesia mengalami peningkatan sebesar 5,32\% dari tahun 2007. Dengan Laju Pertumbuhan Penduduk
(LPP) sebesar $1,28 \%$ yang diperkirakan jumlah kelahiran di Indonesia sebesar 5 juta jiwa per tahun. Mengingat besarnya jumlah kelahiran per tahun maka diperlukan upaya untuk 
mengendalikan kelahiran melalui perencanaan keluarga dengan menggunakan kontrasepsi terutama setelah melahirkan atau mengalami keguguran (Anggraeni,Y, 2012; BKKBN. 2014).

Hasil Survei Demografi dan Kesehatan Indonesia (SDKI) tahun 1991 sampai dengan tahun 2007 menunjukkan trend wanita yang melahirkan di rumah sakit pemerintah dan swasta mengalami peningkatan, namun jumlah persalinan yang meningkat ini tidak diimbangi dengan peningkatan pelayanan KB pascasalin. Rata-rata ibu yang ber-KB setelah bersalin dan keguguran hanya 5-10\% (BKKBN, 2014).

Kontrasepsi pascasalin bertujuan untuk mengatur kelahiran, menjaga jarak kehamilan dan menghindari kehamilan yang tidak diinginkan. (BKKBN, 2014) Pendeknya interval antara persalinan dan kehamilan selanjutnya memberikan sumbangan terhadap angka kematian janin dan anak. Analisis dari survey demografi dan kesehatan pada 17 negara berkembang menunjukkan angka kematian anak dan janin menurun pada jarak interval $>36$ bulan, sebagai tambahan jarak kehamilan yang <24 bulan juga meningkatkan angka kematian ibu dan kejadian komplikasi pada kehamilan (Rustein, 2005; Conde, 2000).

Pelayanan KB di rumah sakit tidak mengalami peningkatan berarti dalam lima tahun terakhir. Hasil SDKI 2012 memperlihatkan hanya terjadi sedikit peningkatan pelayanan $\mathrm{KB}$ di rumah sakit, baik rumah sakit pemerintah maupun swasta, jika dibandingkan dengan hasil SDKI 2007. Pelayanan KB di rumah sakit pemerintah hanya meningkat $0,1 \%$ dari $4,3 \%$ menjadi $4,4 \%$, di rumah sakit swasta hanya $0,1 \%$ meningkat dari 2,2\% menjadi 2,3\% (BKKBN, 2013).

Stagnansi dari peningkatan pelayanan KB diatas disebabkan belum optimalnya konseling sebagai sarana komunikasi informasi dan edukasi (KIE) pelayanan keluarga berencana. Selain itu factor-faktor intern dari masyarakat juga mempengaruhi stagnansi pelayanan $\mathrm{KB}$ diantaranya usia, paritas, usia anak terkecil, pasangan, biaya, kepercayaan dan budaya, tingkat pendidikan, tingkat pengetahuan dan status wanita (BKKBN, 2013).

Metode kontrasepsi jangka panjang (MKJP) dapat diberikan pada 24 jam pascasalin yang kemungkinan dapat diterima oleh pasien karena berkaitan dengan keadaan psikologis pascasalin. Intra uterine devices (IUD) dan metode operasi wanita (MOW) merupakan MKJP yang sangat efektif dan dapat menekan fertilisasi rate (Kemenkes, 2010; BKKBN, 2013).
IUD merupakan pilihan kontrasepsi yang tepat digunakan pada masa pascasalin tanpa melihat status menyusui, karena tidak mempengaruhi kadar hormonal. Pemasangan IUD segera dalam 24 jam setelah persalinan aman, efektif dan tingkat ekspulsi rendah (Development USAoI, 2008).

MOW dapat dianggap sebagai metode kontrasepsi yang tidak reversibel. Metode ini lebih diperuntukkan bagi pasangan yang memiliki cukup anak dan tidak menginginkan untuk menambah jumlah anak lagi. MOW pascapersalinan sebaiknya dilakukan dalam 24 jam, atau selambat lambatnya dalam 48 jam pasca persalinan. MOW pasca persalinan lewat dari 48 jam akan dipersulit oleh edema tuba dan infeksi yang akan menyebabkan kegagalan sterilisasi (Hartanto H, 2010).

Metode KIE digunakan oleh BKKBN untuk menyampaikan pesan dan mengajak masyarakat untuk rela ber-KB. Media dan pesannya disesuaikan dengan tujuan Program KIE. Konseling merupakan tindak lanjut dari KIE. Bila seseorang telah termotivasi melalui KIE, maka selanjutnya ia perlu diberikan konseling (Hartanto H, 2010).

Dalam penyuluhan kesehatan diperlukan cara yang tepat, efektif mudah untuk meningkatkan pengetahuan yang baik. Hal yang cukup penting dalam penggunaan alat peraga adalah alat yang digunakan harus menarik sehingga menimbulkan minat para pesertanya (Notoatmodjo, 2010).

Berbagai media seharusnya dapat dimanfaatkan untuk memberikan penyuluhan termasuk media lembar balik. Konseling KB yang diberikan oleh bidan yang bekerja di poliklinik rumah sakit akan lebih efektif dengan menggunakan lembar balik, namun di ruang perawatan masih jarang digunakan oleh bidan sebagai ujung tombak pelayanan kebidanan dan pelayanan KB karena bentuknya besar, berisi semua metode kontrasepsi dan susah untuk dibawa ke ruangan (BKKBN, 2014; Kemenkes, 2010).

Flash card merupakan salah satu alat peraga atau media berupa kertas/kartu yang berisi suatu masalah atau program tertentu yang dapat digunakan dalam memberikan pendidikan kesehatan. Keunggulan dari flash card yaitu mudah dibawa kemana-mana. Media flash card efektif dalam memberikan konseling yang mudah dibawa ke ruangan perawatan di rumah sakit. Semakin efektif media/alat peraga semakin baik pula pesan yang ditangkap, yang pada akhirnya akan mengubah pengetahuan ibu (WHO, 2006; Kim Y dkk, 2003). Flash card merupakan media 
dan sarana pendidikan kesehatan sebagai upaya untuk menampilkan pesan informasi yang ingin disampaikan tenaga kesehatan kepada klien sehingga dapat meningkatkan pengetahuannya yang akhirnya dapat meningkatkan keikutsertaan KB (Effendi N, 2000).

Upaya meningkatkan kualitas pelayanan $\mathrm{KB}$, dalam arti memenuhi serta memuaskan semua pihak, baik petugas atau konselor maupun klien, perlu dilakukan kegiatan konseling yang memenuhi persyaratan. Keberhasilan dan keberlangsungan pemakaian alat kontrasepsi akan lebih bermakna dan memuaskan apabila konseling dan media yang disampaikan efektif. (Eti R, 2006; Sulistyawati A, 2011; BKKBN, 2006). Berdasarkan uraian diatas tujuan penelitian ini adalah untuk melihat apakah terdapat hubungan antara konseling $\mathrm{KB}$ menggunakan media flash card dengan peningkatan pengetahuan, sikap ibu pascasalin tentang Kontrasepsi IUD dan MOW serta keikutsertaan kontrasepsi IUD dan MOW pascasalin.

\section{METODE}

Penelitian ini merupakan penelitian quasi eksperimen dengan rancangan one group pretestposttest design. Kriteria inklusi pada penelitian ini adalah ibu inpartu kala 1 fase laten atau ibu pascasalin <48 jam dan ibu yang melahirkan secara per vaginam atau per abdomen. Subjek penelitian ini adalah seluruh ibu pascasalin di Rumah Sakit Umum Daerah Cibinong, Kabupaten Bogor. Data dianalisis menggunakan uji wilcoxon, Chi- square dan point bisereal dengan tingkat kepercayaan $95 \%$ dan dianggap bermakna bila $p<0,05$.

\section{HASIL}

Tabel 1. Keikutsertaan Kontrasepsi IUD dan MOW Pascasalin Berdasarkan Karakteristik Subjek Penelitian

\begin{tabular}{|c|c|c|c|c|c|c|c|c|}
\hline \multirow{3}{*}{ Karakteristik } & \multirow{3}{*}{ Kategori } & \multicolumn{4}{|c|}{ Keikutsertaan KB } & \multirow{2}{*}{\multicolumn{2}{|c|}{ Jumlah }} & \multirow{3}{*}{$p$-value } \\
\hline & & \multicolumn{2}{|c|}{ Ikut } & \multicolumn{2}{|c|}{ Tidak KB } & & & \\
\hline & & $\mathbf{n}$ & $\%$ & $\mathbf{n}$ & $\%$ & $\mathbf{n}$ & $\%$ & \\
\hline \multirow[t]{3}{*}{ Umur } & $<20$ tahun & 5 & 83,3 & 1 & 16,7 & 6 & 100 & \multirow{3}{*}{0,844} \\
\hline & 20-30 tahun & 30 & 78,9 & 8 & 21,1 & 38 & 100 & \\
\hline & $>30$ tahun & 7 & 87,5 & 1 & 12,5 & 8 & 100 & \\
\hline \multirow[t]{3}{*}{ Paritas } & 1 anak & 11 & 64,7 & 6 & 35,3 & 17 & 100 & \multirow{3}{*}{0,054} \\
\hline & 2-3 anak & 26 & 92,2 & 2 & 7,1 & 28 & 100 & \\
\hline & $\geq 4$ anak & 5 & 71,4 & 2 & 28,6 & 7 & 100 & \\
\hline \multirow[t]{3}{*}{ Pendidikan } & Dasar & 14 & 77,8 & 4 & 22,2 & 18 & 100 & \multirow{3}{*}{0,519} \\
\hline & Menengah & 24 & 85,7 & 4 & 14,3 & 28 & 100 & \\
\hline & Tinggi & 4 & 66,7 & 2 & 33,3 & 6 & 100 & \\
\hline \multirow[t]{2}{*}{ Pekerjaan } & Bekerja & 15 & 78,9 & 4 & 21,1 & 19 & 100 & \multirow{2}{*}{0,800} \\
\hline & Tidak Bekerja & 27 & 81,8 & 6 & 18,2 & 33 & 100 & \\
\hline \multirow[t]{2}{*}{ Pandangan agama } & Boleh ber-KB & 40 & 81,6 & 9 & 18,4 & 49 & 100 & \multirow{2}{*}{0,523} \\
\hline & Melarang ber-KB & 2 & 66,7 & 1 & 33,3 & 3 & 100 & \\
\hline \multirow[t]{2}{*}{ Akses terhadap Informasi } & Terpapar & 38 & 82,6 & 8 & 17,4 & 46 & 100 & \multirow{2}{*}{0,351} \\
\hline & Tidak terpapar & 4 & 66,7 & 2 & 33,3 & 6 & 100 & \\
\hline \multirow[t]{2}{*}{ Dukungan petugas Kesehatan } & Mendukung & 34 & 82,9 & 7 & 17,1 & 41 & 100 & \multirow{2}{*}{0,446} \\
\hline & Tidak mendukung & 8 & 72,7 & 3 & 27,3 & 11 & 100 & \\
\hline \multirow[t]{2}{*}{ Dukungan suami } & $\mathrm{Ya}$ & 28 & 80,0 & 7 & 20 & 35 & 100 & \multirow{2}{*}{0,840} \\
\hline & Tidak & 14 & 82,4 & 3 & 17,6 & 17 & 100 & \\
\hline \multirow[t]{2}{*}{ Sosial budaya } & Mendukung & 27 & 81,8 & 6 & 18,2 & 33 & 100 & \multirow{2}{*}{0,800} \\
\hline & Tidak mendukung & 15 & 78,9 & 4 & 21,1 & 19 & 100 & \\
\hline
\end{tabular}

Pada tabel 1 di atas menunjukkan bahwa tidak terdapat hubungan secara bermakna $(p>0,05)$ antara semua karakteristik subjek penelitian dengan keikutsertaan KB pascasalin.
Tabel 2. Distribusi Keikutsertaan Kontrasepsi Pascasalin

\begin{tabular}{llcc}
\hline $\begin{array}{c}\text { Keikutsertaan } \\
\text { KB }\end{array}$ & & Jumlah & \% \\
\hline Ikut KB & IUD & 38 & 73,1 \\
& MOW & 4 & 7,7 \\
\hline Tidak Ikut KB & & 10 & 19,2 \\
\hline & & 52 & 100 \\
\hline
\end{tabular}


Berdasarkan tabel 2 di atas diketahui dari 52 orang responden sebagian besar yaitu $80,8 \%$ menggunakan kontrasepsi pascasalin. Kontrasepsi pascasalin yang paling banyak digunakan adalah IUD $(73,1 \%)$.

Tabel 3. Perbandingan Pengetahuan dan Sikap Ibu Pascasalin Sebelum dan Sesudah Pemberian Konseling KB dengan Flash Card

\begin{tabular}{lcc}
\hline \multicolumn{1}{c}{ Variabel } & Jlh & \% \\
\hline Pengetahuan Sebelum konseling KB & & \\
- Baik & 13 & 25,0 \\
- cukup & 21 & 40,4 \\
- kurang & 18 & 34,6 \\
\hline Pengetahuan Sesudah konseling KB & & \\
- baik & 34 & 65,4 \\
- cukup & 11 & 21,1 \\
- kurang & 7 & 13,5 \\
\hline Sikap Sebelum konseling KB & & \\
- mendukung & 22 & 42,3 \\
- tidak Mendukung & 30 & 57,7 \\
\hline Sikap Sesudah konseling KB & & \\
- mendukung & 40 & 76,9 \\
- tidak Mendukung & 12 & 23,1 \\
\hline
\end{tabular}

Berdasarkan Tabel 3 di atas diketahui terdapat peningkatan pengetahuan yaitu dari $25,0 \%$ (13 orang) menjadi $65,4 \%$ (34 orang). dari sikap ibu pascasalin tentang $\mathrm{KB}$, peningkatan dari yang tidak mendukung menjadi mendukung KB yaitu dari $42,3 \%$ (22 orang) menjadi $76,9 \%$ (40 orang).

Tabel 4. Perbedaan Pengetahuan dan Sikap Ibu Pascasalin Sebelum dan Sesudah Pemberian Konseling KB dengan Flash Card

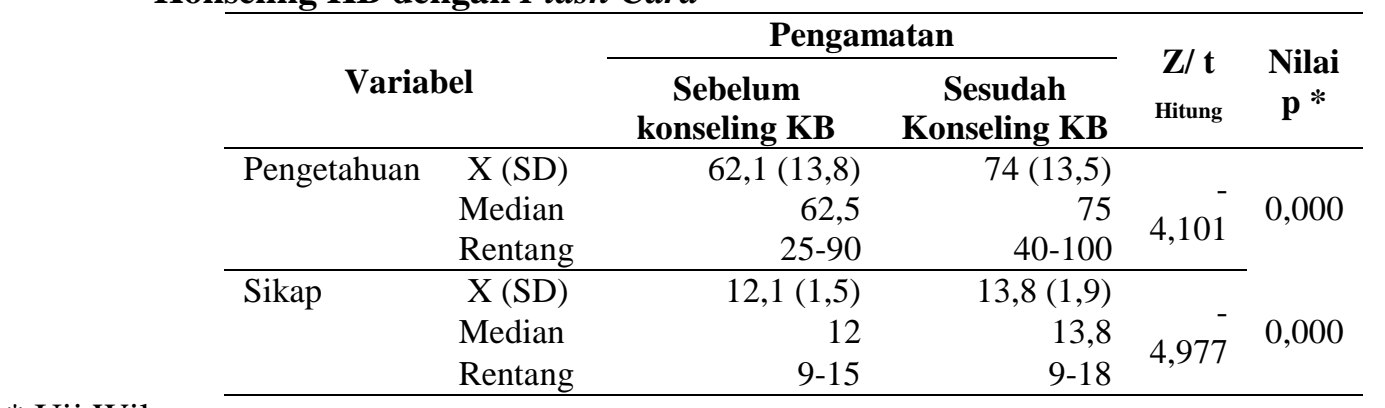

* Uji Wilcoxon

Dari Tabel 4 di atas terlihat bahwa ratarata pengetahuan ibu pascasalin tentang $\mathrm{KB}$ sebelum pemberian konseling $\mathrm{KB}$ adalah 62,1 $(13,8)$, sesudah pemberian konseling KB dengan media flash card meningkat menjadi $74(13,5)$. Rata-rata sikap ibu pascasalin tentang KB sebelum pemberian konseling KB dengan media flash card adalah $12,1(1,5)$, sesudah pemberian konseling KB dengan media flash card meningkat menjadi 13,8 $(1,9)$ sehingga terdapat perbedaan yang bermakna pengetahuan dan sikap ibu pascasalin tentang $\mathrm{KB}$ pascasalin sebelum dan sesudah pemberian konseling $\mathrm{KB}$ dengan media flash card (nilai $\mathrm{p}=0,000$ ).

Tabel 5. Hubungan Pengetahuan Sesudah Pemberian Konseling KB Menggunakan Media Flash Card dengan Keikutsertaan Kontrasepsi IUD dan MOW Pascasalin

\begin{tabular}{|c|c|c|c|c|c|c|c|c|}
\hline \multirow{3}{*}{$\begin{array}{c}\text { Pengetahuan } \\
\text { Sesudah } \\
\text { Konseling KB }\end{array}$} & \multicolumn{4}{|c|}{ Keikutsertaan KB } & \multirow{2}{*}{\multicolumn{2}{|c|}{ Total }} & \multirow{3}{*}{$X^{2}$} & \multirow{3}{*}{ p-value } \\
\hline & \multicolumn{2}{|c|}{ Ikut } & \multicolumn{2}{|c|}{ Tidak Ikut } & & & & \\
\hline & $\mathbf{n}$ & $\%$ & $\mathbf{n}$ & $\%$ & $\mathbf{n}$ & $\%$ & & \\
\hline Baik & 31 & 91,2 & 3 & 8,8 & 34 & 100 & \multirow{4}{*}{14,658} & \multirow{4}{*}{0,001} \\
\hline Cukup & 9 & 81,8 & 2 & 18,2 & 11 & 100 & & \\
\hline Kurang & 2 & 28,6 & 5 & 71,4 & 7 & 100 & & \\
\hline Total & 42 & 80,8 & 10 & 19,2 & 52 & 100 & & \\
\hline
\end{tabular}



Dari tabel di atas dapat dilihat bahwa ibu pascasalin yang pengetahuan tentang KBnya baik sesudah pemberian konseling KB dengan media flash card lebih banyak ikut KB pascasalin IUD dan MOW yaitu 91,2\% dibandingkan dengan yang pengetahuannya cukup $(81,8 \%)$, sedangkan yang pengetahuannya kurang hanya $28,6 \%$ yang ikut KB. Terdapat hubungan yang positif (nilai $\mathrm{p}=0,001$ ) antara pengetahuan ibu pascasalin dengan keikutsertaan kontrasepsi IUD dan MOW Pascasalin.

Tabel 6. Hubungan Sikap Sesudah Pemberian Konseling KB Menggunakan Media Flash Card dengan Keikutsertaan Kontrasepsi IUD dan MOW Pascasalin

\begin{tabular}{|c|c|c|c|c|c|c|c|c|}
\hline \multirow{3}{*}{$\begin{array}{l}\text { Sikap Sesudah } \\
\text { Konseling KB }\end{array}$} & \multicolumn{4}{|c|}{ Keikutsertaan KB } & \multirow{2}{*}{\multicolumn{2}{|c|}{ Total }} & \multirow{3}{*}{$X^{2}$} & \multirow{3}{*}{$p$-value } \\
\hline & \multicolumn{2}{|c|}{ Ikut } & \multicolumn{2}{|c|}{ Tidak Ikut } & & & & \\
\hline & $\mathbf{n}$ & $\%$ & $\mathbf{n}$ & $\%$ & $\mathbf{n}$ & $\%$ & & \\
\hline Mendukung & 38 & 95,0 & 2 & 5,0 & 40 & 100 & 5 & 0001 \\
\hline Tidak Mendukung & 4 & 33,3 & 8 & 66,7 & 12 & 100 & & 0,001 \\
\hline Total & 41 & 80,8 & 10 & 19,2 & 52 & 100 & & \\
\hline
\end{tabular}

Dari Tabel 5 di atas dapat dilihat bahwa ibu pascasalin yang sikapnya mendukung KB sesudah pemberian konseling dengan media flash card lebih banyak (95\%) yang ikut KB IUD dan MOW pascasalin dibandingkan dengan sikap yang tidak mendukung (5\%). Terdapat hubungan positif (nilai $p=0,000$ ) antara sikap dengan penggunaan kontrasepsi IUD dan MOW pascasalin.

Tabel 7. Korelasi Peningkatan Pengetahuan dan Sikap Sesudah Pemberian Konseling KB Menggunakan Media Flash Card dengan Keikutsertaan Kontrasepsi IUD dan MOW Pascasalin

\begin{tabular}{llrrrr}
\hline \multirow{2}{*}{$\%$ Peningkatan } & & \multicolumn{2}{c}{ Keikutsertaan KB } & \multirow{2}{*}{ Nilai p } & \multirow{2}{*}{$\boldsymbol{r}_{p b i s}$} \\
\cline { 3 - 4 } Pengetahuan & Median & 6,25 & 25 & & \\
\multirow{2}{*}{ Sikap } & Rentang & $38,46-70$ & $18,18-280$ & 0,002 & 0,30 \\
& Median & 6,29 & 13,03 & & \\
\cline { 2 - 4 } & Rentang & $20,34-120$ & $17,86-56,41$ & 0,001 & 0,43 \\
\hline
\end{tabular}

Ket: $\boldsymbol{r}_{p b i s}=$ Korelasi Point Biserial

Dari Tabel 5 di atas diketahui terdapat korelasi antara peningkatan pengetahuan dan sikap dengan penggunaan kontrasepsi IUD dan MOW pascasalin nilai $p=0,002$ dan 0,001 dengan tingkat keeratan hubungan lemah dan cukup.

\section{PEMBAHASAN}

Hasil penelitian yang telah dilakukan berdasarkan uji Chi-square dan point bisereal menunjukkan bahwa terdapat hubungan positif antara pengetahuan dan sikap sesudah pemberian konseling KB menggunakan media flash card dengan keikutsertaan kontrasepsi IUD dan MOW pascasalin, sedangkan hasil uji wilcoxon didapatkan bahwa terdapat perbedaan antara pengetahuan dan sikap ibu pascasalin sebelum dan sesudah pemberian konseling $\mathrm{KB}$ menggunakan flash card.

Konseling adalah suatu proses seseorang membantu orang lain dalam membuat keputusan atau mencari jalan untuk mengatasi masalah, melalui pemahaman tentang fakta-fakta dan perasaan-perasaan yang terlibat didalamnya.
(Notoatmodjo, 2007). Konseling merupakan proses yang berjalan dan menyatu dengan semua aspek pelayanan keluarga berencana dan bukan hanya informasi yang diberikan dan dibicarakan pada satu kesempatan yakni saat memberikan pelayanan (Saifudin, 2006).

Konseling KB merupakan percakapan yang bertujuan untuk membantu calon peserta KB agar memahami Norma Keluarga Kecil Bahagia Sejahtera (NKKBS). Dalam konseling $\mathrm{KB}$ informasi yang jelas, tepat dan benar diberikan sesuai dengan kebutuhan klien setelah mendengar apa yang diungkapkan oleh klien (Sulistyawati A, 2011). Dari definisi ini tercakup bahwa peranan satu pihak (konselor KB) yaitu petugas kesehatan termasuk bidan yang membantu pihak lain (klien) melakukan suatu tindakan (Notoatmodjo, 2007). Teknik konseling yang baik dan informasi yang memadai harus diterapkan dan dibicarakan secara interaktif sepanjang kunjungan (Saifudin,2006).

Bidan merupakan salah satu tenaga kesehatan yang mempunyai peran pemberi pelayanan kebidanan, pengelola pelayanan kebidanan, pendidik dan peneliti. Bidan adalah 
ujung tombak pelayanan kebidanan dan pelayanan KB. Didalam pelayanan kebidanan salah satu wewenang bidan adalah memberi pelayanan kebidanan keluarga berencana, sehingga berpengaruh dalam keberhasilan pelayanan keluarga berencana dan kesehatan reproduksi. Oleh karena itu faktor yang sangat menentukan dalam pelayanan tersebut adalah aspek tenaga kesehatan yang berkompeten dalam bidang ini. Salah satu caranya dengan optimalisasi kemampuan bidan dalam memberikan konseling kepada akseptor $\mathrm{KB}$ (Saifudin, 2006; Pusdiknakes, 2006).

Pemberian konseling akan efektif jika menggunakan media. Berbagai media seharusnya dapat dimanfaatkan untuk memberikan penyuluhan termasuk media lembar balik, namun masih jarang digunakan oleh bidan dengan alasan repot dan tidak sempat karena membutuhkan waktu lama dalam penggunannya. Fungsi petugas kesehatan juga tergerus karena kurangnya dukungan. Padahal, petugas kesehatan penting untuk mengedukasi dan memberikan konseling sehingga masyarakat dapat merencanakan keluarga dengan baik dan rasional (BKKBN, 2014; Kemenkes, 2010).

Kegiatan konseling merupakan bagian dari kegiatan pelayanan $\mathrm{KB}$ dan kesehatan reproduksi secara keseluruhan. Dalam pelaksanaannya di lapangan kegiatan ini perlu dibina dan dikembangkan menuju pada pelayanan yang lebih berkualitas dengan jaringan dan pelayanan yang mempunyai sistem rujukan yang dapat diandalkan, sehingga akseptor merasa puas atas pelayanan yang diterimanya (Eti R, 2006). Dalam upaya meningkatkan kualitas pelayanan $\mathrm{KB}$, dalam arti memenuhi serta memuaskan semua pihak, baik petugas konselor maupun klien, perlu dilakukan kegiatan konseling yang memenuhi persyaratan. Dengan komunikasi dan konseling yang efektif, maka keberhasilan dan keberlangsungan pemakaian alat kontrasepsi akan lebih bermakna dan memuaskan. (Sulistiawati A, 2001; BKKBN, 2006).

Konseling KB yang efektif dapat meningkatkan pengetahuan terhadap keluarga berencana yang akan membentuk keyakinan tertentu sehingga seseorang berperilaku sesuai dengan keyakinannya (Notoatmodjo, 2010; Sifudin, 2009). Perilaku merupakan respon atau reaksi seseorang terhadap stimulus (Azwar S, 2000; Simamora B, 2000).

Stimulus dapat diberikan melalui media pendidikan kesehatan, terdapat beberapa kategori media pendidikan yaitu above the line dan below the line. Kategori media yang termasuk dalam above the line adalah film, radio, dan TV. Below the line adalah leaflet, booklet, flip chart, dan flash card (Suiraoka P, 2012).

Penggunaan sebuah media dalam teknik pendidikan kesehatan merupakan hal penunjang keberhasilan dari tujuan pendidikan kesehatan tersebut. Hal ini sesuai dengan yang dikemukakan oleh lembaga riset dan penerbitan komputer, computer technology research (CTR) yang menyatakan bahwa orang hanya mampu mengingat $20 \%$ dari yang dilihat, $30 \%$ dari yang didengar. Akan tetapi orang dapat mengingat $50 \%$ dari yang dilihat dan didengar serta $80 \%$ dari yang dilihat dan dilakukan sekaligus. (Suiraoka P, 2012; Suryanto M, 2009).

Penelitian yang dilakukan oleh beberapa ahli mengidentifikasikan manfaat penggunaan media dalam pendidikan yaitu media dapat memperjelas penyajian pesan agar tidak terlalu bersifat verbalistik. Jika materi hanya disampaikan secara verbalistik, terutama pada sasaran yang memiliki keterbatasan dalam bahasa maka sasaran akan sulit menerima materi yang disampaikan. Hambatan ini dapat diatasi dengan menampilkan gambar atau foto sehingga menimbulkan persepsi yang sama pada sasaran. Media juga dapat mengatasi keterbatasan ruang, waktu dan daya indera (Suiraoka P, 2012; Wiryanto $P$, 2004).

Pada penelitian ini, flash card efektif digunakan sebagai media dalam pemberian konseling KB pascasalin IUD dan MOW. Hal ini dibuktikan dari hasil post-test pengetahuan dan sikap responden lebih tinggi nilainya daripada pre-test.

Hasil penelitian ini sesuai dengan penelitian Mahamed, F. yang menyimpulkan bahwa metode pendidikan kesehatan tentang keluarga berencana yang efektif dapat meningkatkan pengetahuan dan menimbulkan sikap yang baik terhadap program keluarga berencana. Selain itu hasil penelitian Syofia menyatakan terdapat pengaruh penyuluhan dengan flash card terhadap peningkatan pengetahuan dan sikap siswa tentang makanan bergizi, beragam, seimbang dan aman (Mahamed, 2012; Syofia. 2014).

Media flash card merupakan media yang sudah lama dikenal dan digunakan sebagai media visual untuk proses belajar dan mengajar karena memiliki empat fungsi media pembelajaran yaitu fungsi atensi (menarik), fungsi afektif (kenikmatan belajar), fungsi kognitif (memperlancar pencapaian tujuan belajar), dan fungsi kompensatoris (mengakomodasikan siswa yang lemah belajar). Media yang menarik dapat meningkatkan minat dan memudahkan seseorang 
untuk memahami isi materi pendidikan kesehatan yang disampaikan (Suiraoka, 2012).

Flash card mudah dibawa kemana-mana, jika gambar-gambarnya menarik akan merupakan daya rangsang kelompok sasaran untuk memperlihatkan dan mendengarkan secara tekun, dan pokok pembicaraan mudah diingat karena disajikan dalam bentuk cerita gambar (Effendi, 2000). Hal ini sejalan dengan penelitian Sartika bahwa permainan edukatif seperti kartu bergambar (flash card) puzzel, alat menggambar, menggunting, menggambar, simulasi alat kebersihan diri dan bahan makanan meningkatkan skor pengetahuan anak tentang praktik kebersihan diri dan makanan sehat bergizi (Sartika, 2013).

Pengetahuan merupakan domain yang sangat penting untuk terbentuknya tindakan seseorang termasuk kemandirian dan tanggung jawabnya dalam berperilaku. Keikutsertaan kontrasepsi pascasalin sangat dipengaruhi pengetahuan yang dimiliki oleh ibu, tanpa didasari dengan pengetahuan yang baik maka akan memengaruhi penerimaan ibu terhadap KB pascasalin (Azwar S, 2000).

Menurut hasil penelitian Sukaisih, ada hubungan antara pengetahuan tentang kontrasepsi dengan penggunaan alat kontrasepsi pada pasangan usia subur (Trussel J, 1995). Hal ini selaras dengan pendapat Purba (2008) dalam penelitiannya bahwa semakin tinggi pengetahuan maka pemakaian alat kontrasepsi akan meningkat. Pengetahuan yang baik dapat menjadi dasar yang memengaruhi pemilihan alat kontrasepsi yang akan digunakan (Notoatmodjo. 2010).

Penelitian yang dilakukan Dainah menyatakan hal yang sama bahwa pengetahuan yang cukup tentang $\mathrm{KB}$ pascasalin dapat memberdayakan ibu pascasalin dalam membuat pilihan dan keputusan untuk menggunakan KB pascasalin. Tingkat kemandirian setiap individu yang lebih nyata akan bertahan apabila didasari oleh pengetahuan yang kuat (Trussel J, 1995).

Salah satu faktor yang memengaruhi perilaku seseorang adalah pengetahuan. Pengetahuan sebagai faktor predisposisi, yaitu faktor mempermudah atau mempredisposisikan terjadinya perilaku seseorang. Perilaku yang didasari dengan pengetahuan akan lebih baik dari pada perilaku yang tidak didasari dengan pengetahuan (Notoatmodjo, 2003; Wawan A. 2010)

Pengetahuan tentang KB dapat menyebabkan orang menggunakan KB sebaliknya kebiasaan menggunakan pelayanan $\mathrm{KB}$ akan menambah pengetahuan mereka tentang
KB. Dengan pengetahuan yang baik akan membentuk sikap yang positif terhadap KB, yang kemudian akan diikuti dengan perilaku positif pula yaitu dengan ibu menggunakan KB (Azwar S, 2000). Pembentukan perilaku itu sendiri tidak semata-mata berdasarkan pengetahuan, tetapi masih dipengaruhi oleh banyak faktor yang sangat kompleks (Wawan A, 2010).

Sikap ibu pascasalin yang baik atau positif tentang KB dapat berpengaruh terhadap keikutsertaan KB pascasalin. Hal ini didukung oleh teori bahwa sikap terbentuk dari tiga struktur yang saling menunjang, yaitu komponen yaitu komponen kognitif, afektif, dan konatif. Sikap adalah respons tertutup seseorang terhadap stimulus atau objek tertentu, yang sudah melibatkan faktor pendapat dan emosi yang bersangkutan (senang-tidak senang, setuju-tidak setuju, baik-tidak baik dan sebagainya). Newcomb, salah seorang ahli psikologi sosial menyatakan, bahwa sikap merupakan kesiapan atau kesedian untuk bertindak dan bukan merupakan pelaksanaan motiv tertentu. Dengan kata lain, fungsi sikap belum merupakan tindakan (reaksi terbuka) atau aktivitas, akan tetapi merupakan predisposisi perilaku (tindakan) atau reaksi tertutup (WHO, 2006).

Jika dilihat keikutsertaan $\mathrm{KB}$ pascasalin IUD dan MOW pada penelitian ini, dari Tabel 2 dapat diketahui bahwa sebagian besar ibu pascasalin menggunakan KB IUD sedangkan yang menggunakan MOW hanya $7,7 \%$, namun dalam penelitian ini angka ini sudah baik karena sudah sesuai dengan karakteristik responden yang harus menggunakan MOW. Penelitian ini hanya menilai penggunaan KB IUD dan MOW pascasalin dalam 48 jam sehingga tidak dapat di ketahui responden yang menggunakan MKJP (IUD, MOW dan implan) pada 6 minggu pascasalin.

Terdapat faktor lain yang mungkin memengaruhi keikutsertaan KB yang tidak diteliti pada penelitian ini. Faktor-faktor tersebut antara lain seperti riwayat pemakaian kontrasepsi yang lalu, status menyusui, status amenore, status pernikahan, keinginan punya anak, indeks kekayaan, dan lain-lain (Widyastuti, 2014; Ekabua J, 2010).

\section{SIMPULAN}

1. Pengetahuan dan sikap ibu pascasalin tentang KB IUD dan MOW sesudah pemberian konseling $\mathrm{KB}$ dengan media flash card lebih baik daripada sebelum pemberian. 
2. Terdapat korelasi antara peningkatan pengetahuan dan sikap ibu pascasalin tentang $\mathrm{KB}$ sesudah pemberian konseling $\mathrm{KB}$ menggunakan media flash card dengan keikutsertaan kontrasepsi IUD \& MOW pascasalin.

3. Penggunaan kontrasepsi IUD pascasalin lebih banyak dari pada MOW.

\section{SARAN}

1. Penelitian ini dapat digunakan sebagai dasar untuk penelitian lebih lanjut sehingga dapat digali lebih mendalam faktor lain yang memengaruhi keikutsertaan KB pascasalin seperti indeks kekayaan, status menyusui, status amenore, keinginan punya anak, status pernikahan dan lain-lain.

2. Penelitian ini perlu dilanjutkan untuk mengetahui persepsi bidan untuk

\section{DAFTAR PUSTAKA}

Anggraeni Y. 2012. Pelayanan Keluarga Berencana. Bantul Yogyakarta: Rohima Press Sewon.

Azwar S. 2000. Sikap Manusia Teori dan Pengukurannya. Pustaka Pelajar.

BKKBN. 2014. Upaya Meningkatkan Pemakaian Alat Kontrasepsi (KB) Pascapersalinan dan Pascakeguguran di Rumah Sakit.

BKKBN. 2013. Survey Demografi dan Kesehatan Indonesia. Kementerian Kesehatan Republik Indonesia. Jakarta.

BKKBN. 2006. Pedoman Tekhnis Komunikasi Interpersonal/ Konseling KB. Jakarta.

Conde A, Belizan J. 2000. Maternal Morbidity and Mortality Associated With Interpregnancy Interval. British Medical Journal, 321:1255-9.

Development USAoI. 2008. The Postpartum Intrauterine Device: a Training Course for Service Providers New York: EngenderHealth.

Effendi N. 2000. Dasar-dasar Keperawatan Kesehatan Masyarakat 2. Editor. Jakarta: EGC.

Ekabua J, Ekabua K, Odisolu P, Iklaki C. 2010. Factors Associated With Contraceptive Use and Initiation of Coital Activity After Childbirth. Dove Press Journal, 1:85-91. menggunakan media flash card dalam pemberian konseling KB pascasalin.

3. Diharapkan media flash card dapat digunakan di seluruh rumah sakit agar pelaksanaan konseling KB dapat dilaksanakan dengan efektif dan efisien.

4. Diharapkan materi dalam media flash card untuk konseling KB pascasalin lebih menekankan pada efek samping $\mathrm{KB}$ dan faktor sosial budaya.

5. Dalam pemberian konseling KB pascasalin hendaknya ditambahkan muatan agama dan melibatkan suami.

6. Dalam pemberian konseling $\mathrm{KB}$ pascasalin kepada kelompok khusus seperti ibu pascasalin umur $>35$ tahun yang sudah memiliki $>3$ orang anak, lebih ditekankan kepada kehamilan dan persalinan risiko tinggi dan pentingnya $\mathrm{KB}$ untuk kesehatan ibu dan anak.

Eti R. 2006. Hubungan Antara Konseling dengan Kepuasan Aksektor KB di Puskesmas Manyaran Semarang.

Hartanto H. 2010. Keluarga Berencana dan Kontrasepsi. Cetakan 7 ed. Jakarta: Pustaka Sinar Harapan.

Kim Y, Kols A, Putjuk F, Heerey M. 2003. Participation by Clients and Nurse Midwives in Family Planning Decision Making In Indonesia. Patient Educ Couns, $50(3): 295-302$.

Mahamed F. 2012. Impact of Family Planning Health Education on the Knowledge and Attitude among Yasoujian Women. Global Journal of Health Science, Vol 4 (2).

Notoatmodjo S. 2010. Promosi Kesehatan: Teori dan Aplikasi. Jakarta: Rineka Cipta.

Notoatmodjo S. 2003. Pengantar Pendidikan dan Ilmu Perilaku Kesehatan. Yogyakarta: Andi Offset.

Notoatmodjo S. 2007. Pendidikan dan Perilaku Kesehatan. Jakarta: Rineka Cipta.

Purba JT. 2008. Faktor-faktor yang Mempengaruhi Pemakaian Alat Kontrasepsi Pada Isteri PUS di Kecamatan Rambah Samo Kabupaten Rokan Hulu Tahun 2008. Tesis. Medan: Program Pascasarjana IKM USU.

Pusdiknakes Depkes RI. 2006. Kompetensi Bidan Indonesia. PP IBI 
Rustein S. 2005. Effects of Preceding Birth Intervals on Neonatal, Infant and Under Five Years Mortality and Nutritional Status in Developing Countries. The Demographic and Health Survey Int $J$ Gynaecol Obstet. 89:S7-24.

Sartika. 2013. Pengaruh penyuluhan dengan Flash Card Terhadap peningkatan Pengetahuan dan Sikap Anak Balita Dalam Pemilihan Jajanan Sehat.

Saifudin AB. 2006. Buku Panduan Praktis Pelayanan Kontrasepsi. Jakarta: Yayasan Bina Pustaka Sarwono Prawirohardjo.

Simamora B. 2000. Panduan Riset Perilaku Konsumen. Jakarta: PT Gramedia Pustaka Utama.

Suiraoka, P., Supariasa D. 2012. Media Pendidikan Kesehatan. Yogyakarta. Graha Ilmu.

Sulistyawati A. 2011. Pelayanan Keluarga Berencana. Jakarta: Salemba Medika.

Suryanto M. 2009. Multimedia: Alat Untuk Meningkatkan Keunggulan Bersaing. Yogyakarta: Andi Karya.
Syofia. 2014. Pengaruh Penyuluhan Makanan Bergizi Beragam Seimbang dan Aman dengan Menggunakan Flash Card dalam Meningkatkan Pengetahuan dan Sikap Anak Kelas 1-3 SD Islam Titi Berdikari Kecamatan Medan Labuhan.

Trussel J, Leveque JA, Koeniq JD. 1995. The Economic Value of Contraception: a Comparison of Methods. American Journal of Public Health, 85(4): 494-503

Wawan A, Dewi. 2010. Teori dan Pendekatan Pengetahuan, Sikap, dan Partisipsi Manusia. Jakarta: Salemba Medika.

WHO. 2006. Decision-making Tool for Family Planning Clients and Providers: Technical Adaptation Guide. Geneva.

Widyastuti L., Saikia U. 2014. Postpartum Contraceptive Use in Indonesia: Recent Patterns and Determinant.

Wiryanto HP. 2004. Pengantar Ilmu Komunikasi. Jakarta: Grasindo. 